\title{
Strates
}

STRATES Matériaux pour la recherche en sciences sociales

$11 \mid 2004$

Jeune recherche, la vitalité d'un laboratoire

\section{Recherche ou militantisme. Un doctorat dans un pays en guerre}

Irène Salenson

\section{(2) OpenEdition}

1 Journals

Édition électronique

URL : http://journals.openedition.org/strates/422

DOI : $10.4000 /$ strates.422

ISSN : $1777-5442$

Éditeur

Laboratoire Ladyss

Édition imprimée

Date de publication : 1 janvier 2004

ISSN : 0768-8067

Référence électronique

Irène Salenson, «Recherche ou militantisme. Un doctorat dans un pays en guerre », Strates [En ligne], 11 | 2004, mis en ligne le 26 novembre 2008, consulté le 08 septembre 2020. URL : http:// journals.openedition.org/strates/422 ; DOI : https://doi.org/10.4000/strates.422

Ce document a été généré automatiquement le 8 septembre 2020

Tous droits réservés 


\title{
Recherche ou militantisme. Un doctorat dans un pays en guerre
}

\author{
Irène Salenson
}

1 Les lecteurs sont invités pour lire l'article d'Irène Salenson à se reporter à l'édition papier : Laboratoire Ladyss, 2 rue Valette, 75005 Paris.

\section{RÉSUMÉS}

Quelles sont les difficultés que peut rencontrer un doctorant lorsqu'il effectue des recherches dans un pays en guerre? (restriction de l'accès aux sources, interdiction de déplacement ?...). Le cas exposé ici est celui d'un travail de doctorat sur Jérusalem, dont la problématique s'intéresse aux causes mêmes du conflit. Par ailleurs, lorsque le conflit étudié est fortement médiatisé et investi idéologiquement, le doctorant se trouve confronté à la question du militantisme. La posture militante et la posture analytique et réflexive du chercheur sont-elles compatibles? Cet article présente quelques exemples de conséquences négatives de la confusion entre recherche et militantisme. Il ne s'agit pas de prôner la neutralité, probablement impossible à atteindre. Le chercheur peut être politiquement engagé, mais la manipulation des données et des faits à des fins militantes pose problème.

What kinds of difficulties can a doctoral student meet when researching in a country at war? Restricted access to sources and the impossibility to reach certain places are but part of the answer. This paper focuses more specifically on a $\mathrm{PhD}$ on Jerusalem that includes a study of the conflict's causes. When the conflict under scrutiny is given a lot of media coverage and relies on strong ideological commitments, students are confronted to the issue of political activism. Are the militant attitude and the analytical reflection of the researcher compatible? This paper presents a few examples of the negative consequences triggered by the interaction between research and activism. The author's purpose is not to aim at neutrality, which may be impossible 
to reach anyway. Researchers can be committed, but the manipulation of data and facts with political aims in view is highly debatable.

\section{AUTEUR}

IRÈNE SALENSON

Agrégée de géographie, doctorante au Ladyss, boursière Lavoisier. 